\title{
IDENTIFICAÇÃO DE FATORES QUE \\ CONTRIBUEM PARA O USO DA BICICLETA \\ COMO TRANSPORTE URBANO
}

\section{JONARA MACHADO DE OLIVEIRA, M.SC. | UFSC ARNOLDO DEBATIN NETO, Dr. | UFSC}

\section{RESUMO}

Andar de bicicleta é expor-se ao mundo. Deixar as pernas embalarem o movimento, fechar os olhos e sentir o vento no rosto. O corpo parece flutuar no espaço... A paisagem corre rápida ao redor. Na pele sente-se atravessar os raios de sol, filtrados pelas árvores. Folhas caídas estalam sob o peso das rodas. Sensações se misturam: cheiros, sons, luzes, cores. Uma pedalada e muitos metros se foram.

Concentração e força nas subidas são recompensadas com descidas emocionantes e uma vista monumental. Um prazer lúdico e quase infantil toma conta...

Por que andar de bicicleta?

Desde a crise do petróleo de 1979 se discute o uso da bicicleta como meio de transporte. As questões econômicas e ambientais motivaram o início dos debates. Recentemente, a saturação das vias das cidades por automóveis reforçou a importância da bicicleta, agora sugerida como alternativa de mobilidade. Uma boa mobilidade pressupõe acesso amplo e democrático da população ao espaço urbano, contribuindo para sua inclusão social.

Quando vivemos em uma cidade, buscamos usufruir de suas opções realizando trocas culturais, econômicas e sociais. Para efetiválas, precisamos entrar em contato com outras pessoas e outros lugares e fazemos isso através da movimentação no espaço e da comunicação remota. Certas trocas não podem ser desassociadas do espaço físico das cidades e certos grupos só se mantêm ativos através de encontros pessoais e frequentes de seus membros. Estas relações pessoais são dependentes diretas da mobilidade.

Frente a este panorama, o transporte por bicicleta parece solucionar muitas questões. Em comparação com os automóveis, a bicicleta requer menos espaço urbano e menores investimentos em infraestrutura. Ela é mais acessível economicamente, menos poluente e mais democrática, pois pode ser utilizada por pessoas de praticamente todas as idades e condições sociais. As características da bicicleta parecem ser extremamente vantajosas para a mobilidade nas cidades, entretanto, os espaços dedicados a ela ainda são poucos e os ciclistas se vêem numa disputa com veículos muito maiores e mais pesados.

Muitas são as questões a serem respondidas sobre os ciclistas e suas atitudes. O conhecimento sobre seu comportamento e preferências gera poder para planejadores e governos criarem ações eficazes no que concerne o incentivo do uso da bicicleta como meio de transporte.

Os diferentes fatores que motivam o uso da bicicleta vêm sendo amplamente investigados no meio acadêmico, no entanto, a análise da percepção dos ciclistas e sua relação com os espaços ainda é um tema pouco explorado.

Optou-se por realizar o estudo na cidade de Florianópolis, devido ao crescente interesse por este meio de transporte na cidade, déficit de pesquisas sobre percepção de ciclistas no município e melhor acesso do pesquisador aos dados.

Buscando identificar os fatores que contribuem para o uso da bicicleta como meio de transporte, foi realizado um experimento com 20 ciclistas, que desenharam os mapas de seus trajetos, descreveram as características encontradas em cada trecho e responderam a uma entrevista com 52 perguntas.

Através da análise do conteúdo das respostas, os dados obtidos foram categorizados, quantificados, reagrupados e representados em gráficos e mapas de maneira a melhor proceder a análise.

Os fatores objetivos incluem infraestrutura na origem, destino, integração modal e trajetos; e características do terreno e condições ambientais. Em relação a infraestrutura, contribuem para o maior uso da bicicleta a existência de bicicletários bem localizados, abundantes, seguros e que acomodem os variados tipos de bicicleta; a integração modal para transposição de barreiras físicas, como morro e baía; a existência de rotas ciclísticas exclusivas; a continuidade das rotas exclusivas ou compartilhadas; sinalização que reforce a prioridade dos ciclistas; adequação da largura 
das pistas para acomodar a oscilação da bicicleta, principalmente nas subidas; transições bem projetadas e sinalizadas entre ciclovia e vias; eliminação das faixas de tráfego que alargam e afinam; remoção de placas, obstáculos, valas e tachas mal posicionadas e melhora na qualidade e limpeza dos pisos. Em relação às condições ambientais, contribuem para o uso da bicicleta as rotas protegidas do vento; a boa drenagem das vias e ciclovias; a disponibilidade de integração modal para os dias de chuva; vias arborizadas e sombreadas e baixos níveis de poluição do ar.

Os fatores subjetivos incluem a percepção da segurança; o uso desde a infância; o preparo físico gradual; a apreciação do prazer de pedalar; a percepção de vantagem em relação a gastos financeiros, tempo e autonomia; e a aceitação da sociedade.

Para fins práticos, os resultados desta pesquisa podem ser utilizados para o aprimoramento das rotas ciclísticas atuais e projeto de novas rotas; adequação da infraestrutura de apoio à origem e destino, priorização na implantação de integração modal e direcionamento de programas de educação e incentivo ao uso da bicicleta.

Para os ciclistas, espera-se que a publicação desta pesquisa possa expor suas necessidades e os fatores que precisam ser levados em conta em projetos de incentivo a este meio de transporte. 